\title{
A mikroorganizmusok patogenitása és virulenciája: definíciók, példázatok és molekuláris háttérismeretek
}

\author{
Emődy Levente dr. \\ Pécsi Tudományegyetem, Általános Orvostudományi Kar, Orvosi Mikrobiológiai és Immunitástani Intézet, Pécs
}

\begin{abstract}
A fertőző betegségek kóroki hátterének felderítésére irányuló törekvések hosszú időre tekintenek vissza. Fogalmakkal és követelményekkel (posztulátumokkal) igyekeztek körülírni, hogy egy mikroorganizmus mikor tekinthető egy adott fertőző betegség okozójának. Egy patogén rendszertani kategóriába tartozó mikroorganizmus kimutatása a betegből önmagában még nem elegendő bizonyíték arra, hogy a betegségnek valóban az a kórokozója. Igazolni kell a továbbiakban, hogy rendelkezik azokkal a virulenciafaktoroknak nevezett tényezőkkel, amelyek valójában képessé teszik az adott betegség kiváltására. Robert Koch idejében csak fenotípusos ismeretek álltak rendelkezésre, azok figyelembevételével fogalmazta meg posztulátumait. Később, a megszerzett molekuláris ismeretek birtokában, a posztulátumokat molekuláris szinten is értelmezték. A beteg személyét biológiai, szociális és pszichés egységként kezelő holisztikus megközelítésnek is eleget téve, a posztulátumokat a kórokozó mellett az esetben érintett gazdaszervezet egyedi tulajdonságainak figyelembevételével tovább szélesítették. A dolgozat a fenti kérdéseket példákkal illusztrálva tárgyalja, majd kitér a gyakorlati hasznosítás lehetôségeire.
\end{abstract}

Orv Hetil. 2021; 162(50): 1991-1999.

Kulcsszavak: patogenitás, virulencia, posztulátumok, gazdaszervezet, genetikai információ, génexpresszió

\section{Microbial pathogenicity and virulence: definitions, parables and molecular aspects}

Efforts to explore the casual background of infectious diseases have been ambitioned for a long time. Terms and requirements (postulates) have been created to describe in which case a microorganism can be regarded as a causative agent of a given infectious disease. Demonstration of a representative of a pathogenic taxonomic category in the patient, however, does not prove its causative role in itself. It should also be verified if the microbe possesses the socalled virulence factors enabling it to trigger the given disease. At the time when Robert Koch formulated his postulates, only phenotypic characters were at his disposal. Later, in possession of a substantial genetic knowledge, the postulates have been adapted to molecular level. For having a holistic approach, the postulates have been extended also to the host's individual biological, social and psychological attributes. This paper discusses the above issues with examples for illustration, and outlines their practical applicabilities.

Keywords: pathogenicity, virulence, host, genetic information, gene expression

Emődy L. [Microbial pathogenicity and virulence: definitions, parables and molecular aspects]. Orv Hetil. 2021; 162(50): 1991-1999.

(Beérkezett: 2021. május 13.; elfogadva: 2021. június 14.)

\section{Rövidítések}

ail $=($ adhesion invasion locus $)$ adhéziós-inváziós génszekvencia; ColV = kolicin V; COVID-19 = (coronavirus disease 2019) koronavírus-betegség 2019; DNS = dezoxiribonukleinsav; EF2 = elongációs faktor- $2 ;$ ELISA $=$ (enzyme-linked immunosorbent assay) enzimhez kapcsolt immunszorbensteszt; ETEC = enterotoxin-termelő Escherichia coli; $\mathrm{HGT}=$ horizontális géntranszfer; $h l y T=$ hemolizintranszkripciós regulátor gén; inv = invázióért felelős gén; $\mathrm{LD}_{50}=$ (median lethal dose) medián halálos dózis; LPS = lipopoliszacharid; PAI = 
(pathogenicity island) patogenitási sziget; $r f a H=$ a riboszomális faktor antiterminátor fehérje génje; SARS-CoV-2 = (severe acute respiratory syndrome coronavirus 2 ) súlyos akut légúti tünetegyüttest okozó koronavírus-2; $s f r B=$ a nikotinamid-adenin-dinukleotid-foszfát oxidoreduktáz béta-alegység fehérje génje; YadA = Yersinia-adhéziós determináns A-fehérje; $\operatorname{yad} A=$ a Yersinia-adhéziós determináns A-fehérje génje

A közlemény a Magyar Mikrobiológiai Társaság 2020. évi közgyúlésén a virulencia kérdésköréről tartott bevezető előadás alapján készült. Az anyag összeállítása során a téma komplexitásán túl azzal a problémával is szembesülni kellett, hogy az idetartozó fogalmak meghatározása sem egyértelmú, azok az ismeretek bővülése során tartalmilag módosulnak. A szakmai szótárak áttanulmányozása során például a virulenciára vonatkozóan jóval tíz fölötti definíció található [1-4]. Ezek miatt a felfogás és az értelmezés területén észlelhető eltérések miatt látszott érdemesnek összeállítani az előadás írásos változatát, a szakirodalomnak és a szerző ötvenéves kutatói, oktatói és klinikai mikrobiológiai tevékenységének, valamint a hazai és a nemzetközi mikrobiológus-közösségben szerzett tapasztalatainak együttes figyelembevételével. Ezen összeállításban a fontos definíciók kiemelt kezelése mellett az azokra rímelő példák, történetiháttérismertetések, valamint molekuláris összefüggések tárgyalása szerepel. A szerző bakteriológusi hátterére tekintettel a példák elsősorban az orvosi mikrobiológia ezen területéről származnak.

\section{Patogenitás és virulencia a gazda-mikroba kölcsönhatások tülkrében}

\section{Patogenitás}

A virulenciára vonatkozó ismeretek taglalása előtt elengedhetetlen, hogy megismerkedjünk a kórokozó képesség (patogenitás) alapfogalmával, amely egy mikroorganizmus-kategóriára és egy gazdafajra vonatkozó minőségi és általános fogalom. Azt állapítja meg, hogy az adott mikroorganizmus-kategória képviselői az adott gazdafajban betegséget képesek okozni. Itt mindjárt érdemes megjegyezni, hogy a gazdaszervezet tekintetében megkülönböztetünk széles gazdaspektrumú, vagyis számos gazdafajt megbetegíteni képes (euryxen) kórokozókat és ennek ellenkezőjeként szúk gazdaspektrumú (stenoxen) kórokozókat (például Bacillus anthracis, illetve Mycobacterium leprae). Fontos tudnunk azt is, hogy különbséget teszünk feltétlenül (obligát) és feltételesen (fakultatív) kórokozó baktériumok között, amelyek a gazdafaj egészséges egyedeit, illetve ellenkezóleg, azoknak többnyire csak hajlamosító tényező́k által legyengített egyedeit képesek megbetegíteni. Megjegyzendő, hogy a két csoport elkülönítése nem minden esetben egyszerú.

\section{Virulencia}

A virulencia a patogenitással szemben mennyiségi fogalom, amelyet a kórokozó képesség fokának érzékeltetésére használunk. Virulenciakülönbségeket egy kórokozó faj különböző törzsei között állapítunk meg. A kórokozó baktériumok megbetegítőképességének mértéke a különböző virulenciafaktorok függvénye (például adhezinek, toxinok). A virulencia meghatározására in vitro rendszereket vagy kísérleti állatokat használunk, annak figyelembevételével, hogy az ott mért virulenciaértékek az emberre nem mindig érvényesek. A virulencia megváltozhat a kórokozó genomjában bekövetkezett (genotípusos) vagy a csupán a fenotípusában, elsősorban környezeti tényezők hatására bekövetkező (fenotípusos) változások alapján, erre a későbbiekben térünk ki.

\section{A Koch-posztulátumok}

Annak eldöntésére, hogy egy mikroorganizmus egy adott betegség kórokozójának tekinthetó-e, Robert Koch fogalmazott meg bizonyos követelményeket [5], amelyek eredeti szövegezése - szó szerinti fordításra törekedve - a következő:

Elöször, a kórokozó az adott betegség minden esetében legyen jelen, éspedig a patológiai elváltozásoknak és a betegség klinikai lefolyásának megfeleló lokalizációban.

Másodszor, a kórokozó semmilyen más betegségben ne forduljon elő esetlegesen vagy apatogén élősdiként („nicht pathogener Schmarotzer”).

Harmadszor, a kórokozó a szervezetből egyértelmúen izolálható és színtenyészetben kitenyészthető legyen úgy, hogy a betegséget újból ki tudja váltani.

Megjegyzendő, hogy a fertőző betegségekre vonatkozó ismereteink egyre gazdagabb és árnyaltabb volta miatt ezek az egyes baktériumfajokra és törzsekre vonatkozó posztulátumok ma már nem minden esetben érvényesíthetook.

\section{A molekuláris Koch-posztulátumok}

Mivel a kórokozó baktériumok megbetegítőképességének mértéke a különböző, genetikailag meghatározott virulenciafaktorok függvénye, Falkow a Koch-féle elvek figyelembevételével a virulenciafaktorokra vonatkozóan fogalmazta meg a „molekuláris Koch-posztulátumok” névvel jelzett kritériumokat [6]:

- a meghatározott fenotípus legyen jelen az adott mikroba virulens populációiban;

- az ezen fenotípusért felelős gén inaktiválása csökkentse mérhető́n a virulenciát; és

- a kérdéses gén helyreállítása vagy allelikus pótlása állítsa helyre a virulenciát.

A fenti elvek alkalmazásának a modern mikrobiológia számos alapvető felfedezése köszönhető, amelyekre a későbbiekben térünk ki. 


\section{Példázatok és molekuláris magyarázatok a patogenitás és a virulencia témakörében}

A virulencia csak fogalompárjával, a patogenitással együtt értelmezhető. A patogenitás, mint fentebb említettük, kvalitatív fogalom, amely egy egész rendszertani kategóriára (nemzetség, faj) vonatkozóan azt állapítja meg, hogy az valamely fertőző betegség kórokozója. Senki sem kételkedik abban, hogy a Streptococcus pneumoniae az agyhártyagyulladás egyik bakteriális kórokozója, tehát egy patogén faj. Ez azonban nem jelenti azt, hogy ennek a kórokozó-kategóriának minden képviselője ki tudja váltani a betegséget. Ennek feltétele a tokképzés. A tok nélküli mutáns, bár szintén a $S$. pneumoniae nevet viseli, elveszti betegségokozó tulajdonságát, más szóval virulenciáját. Az agyhártyagyulladást okozó képesség tehát nem az egész rendszertani kategóriára, hanem csak annak bizonyos képességekkel, virulenciafaktorokkal rendelkező képviselőire jellemző.

A patogenitással szemben a virulencia a rendszertani kategória meghatározott képviselőjére vonatkozó kvantitatív fogalom, amely in vitro és állatkísérletes rendszerekben (például a halálos dózis $\left[\mathrm{LD}_{50}\right]$ megállapítása) mérhető. Fontos azonban figyelembe venni, hogy a laboratóriumi (állatkísérleti) módszerekkel mért virulencia csak bizonyos megszorításokkal vonatkoztatható a humán szervezetben lejátszódó folyamatokra. A pneumococcusszal végzett hasüregi vagy vénás egérfertőzés már eleve megkerüli az emberi infekció természetes útját, a cseppfertőzést. A végeredmény egérben az emberi tüdőgyulladás vagy agyhártyagyulladás helyett szepszis, de a kísérlet bizonyítja a tok virulenciafaktori szerepét.

Az, hogy egy fertőzés az adott esetben hogyan zajlik le, milyen következményekkel jár, az adott mikrobapopuláció és az aktuális gazdaszervezet közötti kölcsönhatások bonyolult sorozatának függvénye. Fontos, hogy számításba vegyük a gazdafajt és annak konkrét képviselőjét (perszonalizált medicina), egyedi genetikai paramétereit, anatómiai, élettani és patológiai hátterét, valamint immunállapotát. Mindezek együttesen határozzák meg, hogy a kórokozó virulenciatulajdonságai miként képesek kifejeződni és hatékonyan múködni az adott (például immundeficiens vagy ellenkezőleg, specifikus immunitással rendelkező) gazdaszervezetben.

A gazdafajlagosság lehet szúk és széles. Az előbbire példa a Neisseria meningitidis és a Salmonella Typhi, amelyek fajlagos emberi kórokozók, az utóbbira pedig a veszettség vírusa, amely a meleg vérü fajok sokaságát képes megbetegíteni.

Szervrendszeri fajlagosság jellemzi az enterotoxin-termelö Escherichia colit (ETEC): ez az emberi vagy az állati bélcsatornában akkor okoz betegséget, ha a toxin mellett a különböző gazdafajokban hatékony, specifikus kolonizációs faktort is termel, amelynek segítségével a kórokozó a bélcsatornában megtelepszik, a hámsejtek felületén elszaporodik, és a tüneteket kiváltó toxinmenynyiséget bejuttatja a sejtekbe. Ennek hiányában a kór- okozó csak „átszaladna” a bélcsatornán anélkül, hogy masszív toxinhatást tudna kialakítani. A speciális kolonizációs faktorok igénye miatt a gazdaszervezeti és szervrendszeri fajlagosság kombinációja is jellemző az ETECtörzsek esetében. Az ember, a malac és a borjú esetében az adott gazdaszervezet bélhámsejtjei különböző fajlagosságú receptorokkal rendelkeznek a kolonizációs fimbriák számára, amelyek nem „csereszabatosak”.

Életkori fajlagosság jellemzi az enteropatogén E. coli (EPEC) törzseket, amelyek csak csecsemő- és korai kisded korban okoznak betegséget a bélnyálkahártya alacsonyabb „érettségi foka” miatt. Járványtani szempontból természetesen egy idősebb korú személy is jelentőséggel bír, mivel tünetmentes hordozó, és ürítőként egy újabb fertőzés forrása lehet a fogékony korosztályban.

A gazdaszervezet szempontjából különös figyelmet érdemelnek a fakultatín („opportunista”) kórokozók. Ezek a mikrobák egészséges személyekben általában nem okoznak betegséget, de egy alapbetegség miatt a fertőzésre fokozottan érzékeny szervezetben akár halálos kimenetelü fertőzést okozhatnak (Pseudomonas aeruginosa, Candida fajok, Pneumocystis jirovecii). A multirezisztens nosocomialis opportunista kórokozók pedig az egészségügyi ellátás világszerte egyik legjelentősebb kihívását jelentik. Sajnos az is elmondható, hogy a kitett betegpopulációk száma részben az egészségügyi ellátás fejlődése révén is növekszik. A kemoterápia például az alapbetegség korszerü és célzott ellátásához tartozik, ugyanakkor az immunrendszer múködését is gátolva az opportunista kórokozókkal szembeni fogékonyságot növeli. A kórházi osztályon jelen lévő opportunista, multirezisztens mikroba nosocomialis járványok forrása lehet.

A patogenitás és a virulencia fogalmainak pontos értelmezését segítő szemléletes példa adható a fizetőeszközökön keresztül:

Patogenitás = pénznem: fizetésre alkalmas eszköz általában, például magyar forint, euró.

Virulencia = bankjegy: fizetôeszköz számszerú, egyedi névértékkel $(100,200,500$ Ft stb.) bíró címletei, „populációi”. Minél nagyobb a címlet, annál kevesebb példány kell a fizetéshez, „annál virulensebb”.

Szük gazdafajlagosság: magyar forint, mert kevés kivétellel csak hazánkban fogadják el.

Széles gazdafajlagosság: euró, mivel sok országban érvényes.

Korspecifikus morbiditás: a bankjegy érvényességi idejének lejárata.

Avirulens mutáns: sérülés miatt érvénytelenné vált bankjegy.

Opportunizmus: sikeres fizetés érvénytelen bankjegygyel az ellenőrző rendszer (immunrendszer) hiányossága miatt.

Bár a virulencia csak konkrét baktériumpopuláció (törzs) viszonylatában mérhető számszerüséggel, azért speciesszintre vonatkozóan is tudunk bizonyos következtetéseket levonni. Nyilván senki sem kételkedik az 
adott fajba tartozó klónok konkrét vizsgálata nélkül abban, hogy a Yersinia pestis által okozott pestis súlyosabb betegség, mint a Yersinia enterocolitica által okozott hasmenés.

\section{A kórokozó képesség vizsgálatának történeti háttere}

A kórokozó képesség vizsgálata már a kórokozók felfedezésével szinte egyidejüleg elkezdődött. Robert Koch bizonyos posztulátumok, vagyis követelmények teljesülése esetén tekintett egy mikroorganizmust egy meghatározott betegség kórokozójának. Meg kell említeni, hogy Henle már évtizedekkel korábban értekezett a fertőző betegségek kóroktanáról, az általa miazmáknak nevezett oki tényezőkről és a terjedés módjáról [7]. Bár Koch nem utal Henle korábbi munkájára, és a posztulátumaira történő széles körü hivatkozások során is csak az óáltala megfogalmazott tételekre reflektálnak (nem mindig körültekintően), Henle eredeti gondolatainak méltánylásaként a posztulátumokat sokan az ő nevéhez is kötik (Henle-Koch-posztulátumok). A hivatkozásokban a Koch által megfogalmazott szöveget sokszor túl szabadon, sőt Koch szándékával nem egyezően értelmezik magyar és más nyelvű idézetekben, akár tankönyvekben. $\mathrm{Az}$ eredeti három posztulátumhoz Koch közleményének egy későbbi szakaszából vett részlet alapján gyakran egy negyedik kritériumot is hozzáadnak. Azért is volt szükséges ragaszkodni a közlemény korábbi részében az eredeti megfogalmazáshoz, mert csak azok alapján lehet annak folyományait elemezni. Koch az eredetileg előadás formájában elhangzott anyag alapján egy évvel később készített írásos közleményében sok idézőjével ellentétben nem fogalmaz meg konkrétan negyedik pontot, de annak egy későbbi bekezdésében mintegy a harmadik pontját erősíti meg. A posztulátumokat a hivatkozókkal ellentétben nem számokkal, hanem szóbeli sorrend jelzésével adja meg. Úgy fogalmaz, hogy ha csak az első két követelmény teljesül, vagyis amikor a kórokozót rendszeresen és kizárólagosan mutatjuk ki a betegben, akkor alapos okunk van arra, hogy a parazita és a betegség közötti oki összefüggést egyértelmúen bizonyítottnak tekintsük. Ebből a feltevésből kiindulva azután egy sor olyan betegség esetében, amelynél az okot nem vagy nem teljesen ismerjük, kísérleti állatok oltásával szolgáltathatunk bizonyítékot a harmadik pontra. Koch nagy érdeme ezzel, hogy programot ad a virulencia kutatására abban az időben, amikor arra még csak fenotípusos bélyegek alapján volt lehetőség. Nem méltányos a mai tudásunk alapján kritizálni a pontokat, legfeljebb Koch érdemeinek elismerése mellett kiigazításokat tehetünk. A színtenyészet értelmezését tekintve pedig az értekezés szövegében a hastífusszal kapcsolatban világossá teszi, hogy a patológiai elváltozásoknak megfelelő színtenyészet elófordulását a nyirokcsomókra, a lépre és a májra érti, nem pedig a bélcsatornára, ahogy azt egyes kritikák feltételezik.
A múlt század közepétól a klasszikus bakteriológiai genetika módszereinek birtokában (konjugáció, transzdukció, transzformáció) a virulencia hátterének pontosabb elemzése vált lehetővé, de alapos értelmezés nélkül még mindig pontatlan következtetésre lehetett jutni. Az E. coli ColV-plazmidjának átvitelével például, amely a ColV-bakteriocint kódolja, a recipiens származék virulenciája egérben szignifikánsan megnőtt [8]. Kézenfekvő volt arra gondolni, hogy a ColV egy virulenciafaktor. Mint azt Falkow és mtsai később kimutatták, a virulencia akkor is fokozódott, ha az átvitel előtt a ColV termeléséért felelős gént a plazmidon inaktiválták [9]. A plazmid alaposabb analízisével Williams és Warner azon egy vaskötő anyag (aerobaktin) szintéziséért felelős gént izoláltak. Ennek inaktiválása esetén a plazmid átvitele a virulenciát nem fokozta, a ColV-termelés képességét viszont továbbra is kódolta, vagyis a virulenciafaktor nem a ColV, hanem az azonos plazmid által kódolt aerobaktin [10].

\section{A molekuláris Koch-posztulátumok}

A ColV- és aerobaktintermelés genetikai hátterének konjugációs kísérletekkel történő tisztázásánál azonban Falkow munkacsoportja nem állt meg. A Yersinia pseudotuberculosis inv-génjében idéztek elő helyspecifikus mutációt, majd visszaállították annak eredeti szekvenciáját. A mutáció a törzs hámsejtekbe történő penetrációs képességét jelentősen csökkentette, a gén helyreállítása pedig visszaállította azt az eredeti szintre [11]. Mivel a gén inaktiválásával a penetrációs képesség csak csökkent, de nem szûnt meg, a jelenség hátterében más gének szerepét is feltételezték, majd bizonyították (ail) [12]. Az inv-gén DNS-szekvenciája alapján előfeltételezték a kódolt „invasin” fehérje aminosav-összetételét, amit annak izolálásával és szekvenálásával igazoltak is. Falkow tehát nem egy baktériumtörzs teljes virulenciájára, hanem - ahogy hangsúlyozta is - egy virulenciafaktor szerepére vonatkozóan vont le következtetéseket. Ezek alapján az általa megfogalmazott és fentebb ismertetett „molekuláris Koch-posztulátumok” is egy meghatározott tényezőre érvényesek [6]. 15 évvel később Falkow a posztulátumok további, dinamikus értelmezését vetette fel, amit a molekuláris módszerek állandó fejlődése tett szükségessé. Kifejtette a gazdaszervezeti válasz bevonásának szükségességét [13].

Természetesen, a tulajdonságot kódoló strukturális gén mellett a szabályozórendszer múködése is szükséges a funkcióképes géntermék megjelenéséhez. Más szóval, a génfunkció az ép strukturális gén jelenlétében nem fejeződik ki, ha a génregulációs rendszer nem olyan irányban múködik. Különösen nagy jelentősége van az ún. globális regulátor géneknek, amelyek egyszerre számos gén - köztük virulenciagének - múködését is vezérelhetik. Ennek a virulenciavizsgálatok szempontjából nagy jelentősége van, ugyanis különböző szerzők ugyanazt a regulátor gént különböző neveken írták le az általuk 
vizsgált fenotípusos funkcióhoz kapcsolódó névvel. Erre a regulátor gének DNS-szekvenciájának meghatározása derített fényt [14]. A szakirodalomban a leggyakrabban $r f a H$ néven említett regulátor gén allelikus például a hlyT és sfrB regulátor génekkel, amint azt bázisszekvenciájuk megismerése kiderítette. Ennek a génnek az inaktiválása az E. coli 536 törzs esetében egyaránt gátolja a hemolizin, a tok és a lipopoliszacharid (LPS) szintézisét, ezáltal legalább három virulenciafaktor múködését egyszerre befolyásolja [15]. Ez azt jelenti, hogy a molekuláris Koch-posztulátumok alkalmazása esetében nem mindegy, hogy egy strukturális gén vagy egy regulátor gén virulenciára gyakorolt hatását vizsgáljuk. Az utóbbi - pleiotrop hatása révén - lényegesen nagyobb befolyást gyakorolhat a törzs kórokozó képességére.

\section{A virulenciagének lokalizációja}

A virulenciagének lehetnek a kromoszóma részei, de elhelyezkedhetnek önálló replikonokon is. A kromoszomális lokalizáció esetén lehetnek az alapkromoszóma részei, de integrált plazmidok, fágok és patogenitási szigetek (PAI-k) formájában is elófordulhatnak. A plazmidok megőrizhetik autonómiájukat, ilyenkor extrakromoszomális elemként önállóan replikálódva kódolnak virulenciafaktorokat, mint a már említett ColV-plazmid.

\section{A virulencia evolúciója}

Horizontális géntranszfer (HGT) révén a genetikai információ kicserélődhet két baktérium között. A genetikai információ átadása a virulencia jelentős fokozódását okozhatja egyetlen lépésben („evolution in quantum leap”), de a lépések sorozata is követheti egymást. A HGT kiemelt szerepet játszik nemcsak a virulencia, de az alkalmazkodóképesség fokozódása és az antibiotikumrezisztencia terjedése szempontjából is.

A PAI-k a baktérium kromoszómájába integrálódott idegen DNS-elemek, amelyek ha más nemzetség képviselőjéból származnak, akkor $\mathrm{G}+\mathrm{C}$ arányuk különbözik az alapkromoszóma $\mathrm{G}+\mathrm{C}$ arányától, ezzel mintegy kakukktojásnak tekinthetők a „háztartási” gének között [16]. A hasonlat még annyiban is találó, hogy a kikelő kakukkfiókákhoz hasonlóan, amelyek az eredeti anya fiókáit kipenderítik a fészekból, sok esetben ezeknek a géneknek a termékei veszik át az irányítást, legalábbis a virulencia tekintetében. Így van ez a diftériatoxin termelését kódoló, integrálódott fággenom és a húgyúti fertőzést okozó baktériumok többtényezős virulenciamechanizmusa esetében is. A PAI- $\mathrm{k}$ terjedése nem tiszteli a fajok vagy akár a nemzetségek határait. Az E. coli hemolizinoperonja például a Proteus penneriben és a Morganella morganiiban is megtalálható. Az igazság kedvéért azt is el kell mondani, hogy a sorrend tekintetében nem is ez a helyes evolúciós megközelítés. Az őstípus valójában a $P$. penneri, amelynek $38 \%$-os kromoszomális $\mathrm{G}+\mathrm{C}$ hányadosa azonos a hemolizinoperon $\mathrm{G}+\mathrm{C}$ há- nyadosával, szemben az E. coli alapkromoszómájának kb. 50\%-os G + C arányával. A fentieken kívül az operon a Proteus vulgaris, Enterobacter cloacae, Mannheimia haemolytica, Aggregatibacter actinomycetemcomitans, Actinobacillus pleuropneumoniae, Moraxella bovis és Bordetella pertussis esetében is integrálódott PAI-ként kódolja ezt a toxint.

A Corynebacterium diphtheriae kromoszómájába integrálódott bakteriofág-genom, amely a diftériatoxin termelését kódolja, virális eredetû PAI-nak tekinthető [17].

Egy másik útja a virulencia fejlődésének a patoadaptív mutáció, amely az eredeti kromoszómán vezet olyan változásokhoz, amelyek a virulencia finomhangolását idézik elő az aktuális gazdaszervezeti környezethez. Ennek példája a mannózt felismerő fimbriák adaptív affinitásváltozása, idomulva a gazdaszervezet mannóztartalmú molekuláinak finomszerkezetéhez, vagyis a mannózmolekulák pozíciójához a kötésért felelős molekuláris „horonyban”. Az uropatogén E. coli mannózt felismerő fimbriájának csúcsalegysége nagyobb affinitással kötődik a hólyag hámsejtjeinek felszíni mannozidjaihoz, mint a bélhámsejtekhez, így szervrendszeri tropizmussal fokozza annak kórokozó képességét a húgyúti rendszerben. Az enteralis kórokozó Salmonella Typhimurium hasonló fimbriája viszont magasabb affinitással kötődik a bélhámsejtekhez, mint a hólyaghám sejtjeihez [18].

Az önálló replikonokként a citoplazmában elhelyezkedő plazmidok által közvetített virulenciatulajdonságok előfordulása szintén gyakori. Amennyiben önmaguk konjugációs készséggel rendelkeznek, vagy egy konjugatív elem segítségével jutnak át más baktériumba, akkor a fertőző antibiotikumrezisztencia mintájára fertőző virulenciáról beszélhetünk. „Kihígulhatnak” a baktériumsejtből, de a fogékony gazdában nem ez jellemző, mivel jelenlétük szelektív előnyt biztosít a kórokozó számára. Amennyiben a kromoszómába integrálódnak, akkor azzal együtt replikálódva a környezetben szelektív nyomás nélkül is stabilak maradnak.

Egy plazmidon akár több virulenciagén is lehet, így az ETEC ugyanazon plazmidja a toxin és a kolonizációs faktor genetikai információját is hordozhatja, amelynek átadásával egy addig ártalmatlan baktériumot egy lépésben (quantum leap) kórokozóvá tehet [19]. Mint fentebb említettük, a különböző gazdafajok esetében a kolonizációs fimbriák fajlagossága is különböző, a kolonizációs faktorok a szervrendszeri fajlagosság mellett gazdaszervezeti fajlagosságot is hordoznak. Az ugrásszerü változás tehát csak az adott kolonizációs faktorra fogékony gazdafajra érvényes.

A virulenciaplazmidok szerepének és egyben a virulencia fejlődésének érdekes példáját adják az emberi kórokozó Yersinia fajok. Ezek különlegesen „kifinomult” volta miatt érdemesnek látszik részletesebben foglalkozni velük. A nemzetség számos állati kórokozó fajt foglal magában, de a három emberi patogén faj is zoonotikus természetű. Közülük kettő enteralis úton terjedő beteg- 
séget okoz, de a harmadik, a pestis kórokozója a genetikai struktúrája alapján rendszertanilag szintén a bélbaktériumok családjának és ennek a nemzetségnek a tagja, annak ellenére, hogy a fertózés átvitele, valamint az okozott tünetek típusa és súlyossága szempontjából teljesen eltér a két másik speciestől. Közös virulenciaplazmidjuk számos virulenciatulajdonságot kódol, amelyek közül a szekretoros rendszeren keresztül a gazdasejtbe „injekciózott”, károsító fehérjéken kívül a YadA (korábban Yopl) nevü fehérje bír jelentős szereppel [20]. A YadAmolekula a fagocitózis gátlásával, a mátrixfehérjékhez való kötődésével és szérumrezisztencia előidézésével segíti a baktérium terjedését a gazdaszervezetben [21]. Ezeknek a fehérjéknek az expressziója adaptálódott a meleg vérü gazda és patkány rezervoár testhőmérsékletéhez, alacsonyabb hőmérsékleten a bolhavektorban nem fejeződnek ki. A közös virulenciaplazmid azonban bizonyos mértékben eltérő a pestis kórokozója esetében. A yadA-gén korai szekvenciájában található kereteltolódási mutáció miatt az általa kódolt fontos fehérje a $\Upsilon$. pestis esetében nem jelenik meg $[21,22]$. Ennek eredményeként a speciesre jellemző rendkívüli invazivitás helyett inkább csökkent kórokozó képességet várhatnánk. A $\Upsilon$. pestis azonban rendelkezik két olyan további plazmiddal, amely a két másik speciesben nincs jelen [23]. Egyikük egy fehérjetokot és egy foszfolipáztoxint kódol, a másik pedig egy plazminogénaktivátort. A tok biztosítja a fagocitózissal szembeni rezisztenciát, a két enzim pedig a direkt invazivitást szolgálja. A plazminogénaktivátor egyrészt fibrinolitikus hatásával (lásd a Streptococcus pyogenes esetében is) segíti az inváziót, de mint nem „szubsztráthüséges” enzim köti és elbontja a bazális membrán egyik alapvető komponensét, a laminint, amivel a kötőszöveti terjedés képességét is fokozza. (Érdemes megjegyezni, hogy az ép yadA-gént tartalmazó virulenciaplazmid bevitele csökkenti a $\Upsilon$. pestis virulenciaját.) Egy másik fontos különbség az enteralis Yersina kórokozókkal szemben, hogy a $\Upsilon$. pestis endotoxin-molekulája nem tartalmaz ismétlődő oligoszacharid-egységekből álló oldalláncot, vagyis természetes R-mutáns [24]. Endotoxinjának bőrvérzéseket okozó hatása (fekete halál) sokkal kifejezettebb a legtöbb Gram-negatív baktérium ilyen hatásánál. (Megint csak érdemes megjegyezni, hogy a rövid oldalláncú lipooligoszacharidot képezó meningococcusnak is hasonlóan eróteljes a petechiákat és purpurákat okozó hatása.) Emellett ez a speciális endotoxin-molekula kevésbé indukálja a „Toll-like” receptorok által történő felismerést és citokintermelést [25]. A több világjárványt okozó kórokozó - archeológiai leleteken végzett, DNS-alapú vizsgálatok eredményei szerint - már ötezer évvel ezelőtt jelen volt emberekben, magas virulenciával rendelkező változata pedig nagyjából négyezer éve jelent meg [26]. A $\Upsilon$. pseudotuberculosisból történő kialakulásának kezdetét mintegy húszezer évvel ezelőttre teszik.

A fertőzés lefolyásában szerepet játszó gazdaszervezeti tényezők szempontjából ugyancsak példaként és konk- rét tanulságos esettel is szolgálhat a Yersinia nemzetség. Mindhárom humán kórokozó fajának számára fontos a vaskötő molekulák jelenléte - ezek a szabad vasban szegény szövetekben a gazdaszervezet vaskötő anyagairól magasabb affinitási konstansaik révén „lelopják” a szaporodásukhoz szükséges $\mathrm{Fe}^{+++}$-ionokat. Enélkül a gazdaszervezeti környezetben nem tudnának szaporodni. A vastárolási betegségekben szenvedók által szedett, vaskiürítést segítő gyógyszerek révén mobilizált vasat mindhárom species fel tudja használni. Ismert, hogy az enteropatogén yersiniák által okozott szisztémás fertőzések gyakorisága magasabb az ilyen betegekben. Haemochromatosisban szenvedő betegben pedig még a laboratóriumban attenuált, sziderofórdeficiens $\Upsilon$. pestis vakcinatörzs is halálos fertőzést okozhat, mint ahogy az egy ilyen baktériummal foglalkozó kutató esetében sajnálatosan meg is történt [27].

\section{A virulenciagének expressziója}

A kórokozó képesség szempontjából fontos tényező az egyes tulajdonságok kifejeződésének alkalmazkodása a gazdaszervezetben adott környezeti tényezőkhöz. A P-fimbriák és az említett Yersinia fajok számos felületi fehérjéje például nem fejeződik ki szobahőmérsékleten, de $37{ }^{\circ} \mathrm{C}$-ra emelve a tenyésztési hőmérsékletet már 5 percen belül kimutathatók [28]. Ez jelzi a gazdaszervezeti hőmérséklethez történő gyors alkalmazkodás képességét. Más szóval a baktérium energetikailag takarékos üzemmódban van akkor, amikor egy virulenciafaktorra nincs szüksége. A hajfonatszerú curli fimbria a húgyúti E. coli törzsek többségén viszont éppen $30^{\circ} \mathrm{C}$ hőmérsékleten fejeződik ki, a gazdaszervezet testhőmérsékletén pedig nem [29]. Ezért első megközelítésben úgy túnik, hogy ez a felszíni képződmény nem szerepelhet virulenciafaktorként. Ha meggondoljuk azonban, hogy az alacsonyabb hőmérsékleten nagy aggregátumokat alkotó curlitermelő baktériumok a béltraktusból a gátra kerülnek ki, akkor az ottani bőrhőmérséklet éppen egy masszív előkolonizációt tesz lehetővé, ahonnan a húgyutakba kerülve a fajlagos kolonizációs fimbriák testhőmérsékleten perceken belül megjelennek. Mindez a baktérium 20-30 perces generációs idejét, vagyis a DNSreplikációtól az osztódás befejeződéséig eltelt időt tekintve nem is nevezhető meglepően rövid időtartamnak. Szemben sok antibiotikumrezisztencia-mechanizmussal, amelyek az antibiotikum jelenléte nélkül, konstitutív módon fejeződnek ki, itt induktív expresszióról van szó, vagyis ez az energiaigényes folyamat csak akkor lép múködésbe, ha annak „ára” bőségesen megtérül a baktérium számára a virulencia fokozódása révén.

A virulencia aktuális kifejeződésében, mint fentebb már szó volt róla, kiemelkedő szerepet játszanak a globális regulátorok, amelyek egyidejúleg számos fenotípusos tulajdonság megjelenését szabályozzák. Az E. coli vonatkozásában már említett $r f a H$-gén virulenciára gyakorolt hatását [15] S. Typhimurium esetében is sikerült bizo- 
nyítani [30]. A gén inaktiválásával attenuált származék oralis halálos dózisa az eredeti törzzsel összehasonlítva 10 000-szeres növekedést mutatott egérmodellben. Ugyanakkor immunizációs kísérletekben a származék protektív hatásúnak bizonyult a vadtörzzsel szemben. A globális jelző tehát nemcsak azt jelenti, hogy egy törzsön belül sokszoros a gén regulációs hatása, hanem a különböző rendszertani entitások, mint például az Escherichia és a Salmonella közötti elterjedtségére is utal.

\section{A virulenciamechanizmusok példái}

A sokszínú mechanizmusok közül két jellegzetes minta bemutatására szorítkozunk.

\section{A diftéria példája [17]}

A kórokozó patogén faj: C. diphtheriae.

Virulenciaprincípium az exotoxin.

Minden képviselője okozhat diftériát? Nem! A toxint nem termelö törzs avirulens, tehát nem okoz diftériát.

A virulens törzs mindenkiben képes diftériát okozni? Nem! Az immunis szervezetben nem okoz diftériát. Nem immunis szervezetben is tünetmentes maradhat a fertőzés, de immunitást válthat ki!

Immunis személy lehet a fertőzés forrása? Igen, mert az antitoxikus immunitással rendelkező személy hordozhatja és ürítheti a kórokozót a felső légútjaiban.

A kórokozó kimutatása elég a bakteriológiai diagnózishoz? Nem, mert a virulenciát, vagyis a toxintermelő képességet is igazolni kell (például a magyar vonatkozású, Elek-féle gélprecipitációs próbával).

Mi a toxinhatás kettős feltétele?

1) A kromoszómába integrálódott, toxintermelésért felelős profág eredetű gén jelenléte és expressziója. A toxintermelés egy $\mathrm{Fe}^{++}$-ion által regulált represszor gén hatása alatt áll. A derepresszió alacsony vasionszint esetén valósul meg. Roux megfigyelése volt, hogy csak a szokásosnál hosszabb ideig inkubált tenyészetek baktériummentes szürlete pusztította el a tengerimalacokat. Jóval késóbb derült ki, hogy a baktériumok által „elhasznált” vasionok miatt lecsökkent vasszint következtében szűnt meg a represszori funkció.

2) Fogékony gazdaszervezet, sejtfelület és célmolekula: a toxinmolekula kötő alegysége (B) kötődik a sejtfelületi receptorához. Az internalizáció után a toxinmolekula a vakuólumból a citoszolba kerül, aktív (A-) alegysége ADP-ribozil-csoportot kapcsol a fehérjeszintézishez elengedhetelen elongációs faktor-2 (EF2-) célmolekula megfelelő helyére. Az EF2-molekulán a kapcsolódási hely a diftamidnak nevezett hisztidinvariáns aminosav. Ha az EF2 csak a jól ismert aminosavakból épülne fel, nem lenne diftéria.

Az exotoxin mint egyetlen és antigenitásában egységes virulenciafaktor előnyt jelent a virulencia mérésében, va- lamint a specifikus kezelés és megelőzés (toxoid védőoltás) lehetőségének szempontjából:

A gyógykezelés (Emil von Behring, az első orvosi Nobel-díj, 1901) alapja az egyetlen toxintípusra alapozható antitoxikus terápia.

$\mathrm{Az}$ antitoxikus immunstatus egyszerü mérése lehetséges ELISA-módszerrel (korábban Schick Béla bőrpróbán alapuló biológiai módszerével, amely a gyakorlatban már nem játszik szerepet).

\section{Példa a soktényezốs virulenciamechanizmusra} [31] búgyúti E. coli fertözés

A kórokozó a leggyakrabban a beteg saját bélflórájából származik, ahol kórokozó képességgel nem rendelkezik. A kiválasztórendszerben kolonizációs fimbriái révén felismeri a húgyúti hámsejtek fajlagos receptorait, azokon megtapad, majd a sejtek felületén elszaporodik. Szaporodását különböző vaskötő vegyületei (sziderofórok) segítik elő, amelyek lehetővé teszik, hogy az anyagcseréjéhez feltétlenül szükséges $\mathrm{Fe}^{+++}$-ionokat magasabb affinitási konstansuk révén a gazdaszervezet sziderofórjairól „lelopja”. A felületi LPS az endotoxin-funkciója révén vesz részt a kórfolyamatban. Tokantigénjei ellenállóbbá teszik a fagocitasejtek bekebelező hatásával szemben.

Figyelemre méltó, hogy a húgyúti és egyéb extraintestinalis fertőzést okozó törzsek esetében gyakori Kl- és K5-tokantigének molekuláris mimikri révén megkerülik az immunfelismerést. (Érdemes megjegyezni, hogy az E. coli Kl-antigénje, amely az újszülöttkori meningitisnek is gyakori kórokozója, identikus a $N$. meningitidis B-csoport tokantigénjével. Ez magyarázza az azonos organotropiát, valamit azt, hogy a $N$. meningitidis B ellen nem sikerült hatásos tokantigén-alapú vakcinát kifejleszteni.)

A csillómozgás a vizeletárammal szembeni haladást segíti elő. A nem teljesen korrekt módon hemolizinnek nevezett, általános citotoxin a falósejteket is pusztítja, valamint a hámsejtek károsítása révén elősegíti a szövetek invázióját. A béltartalomban csak kis százalékban jelen lévő húgyútikórokozó-típus ezen virulenciafaktorok révén ellenáll a vizelet „kimosó” hatásának, szelektíven kolonizál a hólyagban, citotoxinjával károsítja az elsőrendű immunválaszban részt vevő sejteket, ezáltal a bakteriológiai diagnózis idejére már szinte mindig színtenyészetben van jelen a vizeletmintában.

\section{A virulenciavizsgálatok gyakorlati hasznosítása}

A virulenciamechanizmusok felderítése, az elméleti alapok ismerete a sikeres gyakorlati alkalmazás feltétele. A kórokozók elleni küzdelemre is érvényes a hadviselés alapvető szabálya: ismerd meg az ellenséget. A virulenciavizsgálatok eredményeinek hasznosítása már régóta 
része a gyakorlati orvostudománynak a diagnosztika, a terápia és a megelőzés területén egyaránt, amint azt a diftéria példája is mutatja.

A kóroki diagnosztikában a feltételezett ágens rendszertani azonosítása gyakran nem elegendő a virulenciafaktorok vagy az azok képződéséért felelős gének azonosítása nélkül. A bélrendszeri betegségeket okozó E. coli esetében például a diagnózishoz igazolni kell, hogy a bélcsatornában nemcsak mikrobiotatagok, hanem egy enteralis kóroktani egység képviselője is jelen van. Az antitoxikus kezelés az exotoxinok kóroki szerepének tisztázása után a virulenciafaktorra irányuló célzott terápia eszközévé vált. Számos védőoltás szolgál a virulenciafaktorokat közömbösítő fajlagos ellenanyagok termelésére. A járványtani vizsgálatokban a kórokozók klonális összefüggéseinek felderítése segít a terjedési folyamat elemzésében.

A fenotípusos bélyegeken túl a molekuláris szintû ismeretek ma már elengedhetetlenek a fertőző betegségek korszerú diagnosztikai, kezelési, megelőzési és járványtani módszereinek gyakorlatához. A genetikai háttér, az expressziós folyamatok és a gazda-kórokozó kölcsönhatásokon alapuló hatásmechanizmusok sokkal mélyebb feltárása révén a sikeres „hadviselés” lehetőségei is kiszélesedtek. Az eredményes kezelés szempontjából fontos, hogy az antibiotikumterápia mellett vagy azzal együttesen, az egyre terjedő multirezisztenciára tekintettel alternatív beavatkozási eszközökkel is rendelkezzünk [32]. A molekuláris Koch-posztulátumok segítségével kétséget kizáróan tudjuk azonosítani a virulenciafaktorok strukturális génjeit. A DNS-szekvenálás révén vált lehetôvé az addig különböző entitásoknak tartott regulátor gének globális regulátorként történő azonosítása. Ezek "lecsendesítése” egyszerre több virulenciafaktor kikapcsolását eredményezheti. Ilyen perspektivikus lehetőség az egész kórokozó-populáció expressziós tevékenységét befolyásoló „quorum sensing” mechanizmus gátlása [33]. Emellett eredményre vezethet egy, a gazdaszervezet káros reakcióinak mérséklésére irányuló eljárás kifejlesztése. Erre példa a Janus-kináz-gátlók használata az eltúlzott citokintermelés megelőzésére [34]. A rekombináns technológiák alkalmazása a megelőzés területén is új perspektívát jelent, amint ezt a hepatitis B-vakcina és a SARS-CoV-2-védőoltások példája is mutatja A globalizáció korában a molekuláris biológiai módszerek alkalmazása a kórokozók terjedésének és változásaik követésének is elengedhetetlen eszközévé vált, amire a COVID-19-pandémia szintén példaként szolgál.

Végül elengedhetetlen megjegyezni, hogy a virulenciavizsgálatoknak az etikai szempontok szigorú betartásával és kizárólag az emberiség érdekében van létjogosultságuk [35].
Anyagi támogatás: A közlemény megírása anyagi támogatásban nem részesült.

A szerző a cikk végleges változatát elolvasta és jóváhagyta

Érdekeltségek: A szerzőnek a közleménnyel kapcsolatban nincs anyagi érdekeltsége.

\section{Köszönetnyilvánítás}

A szerző köszönetét fejezi ki Nagy Béla akadémikusnak, aki a kézirat megírására bátorította, annak összeállítását hasznos megjegyzéseivel és kritikai észrevételeivel segítette.

\section{Irodalom}

[1] The Free Dictionary. Virulence. Available from: https://www. thefreedictionary.com/virulence.

[2] Oxford Learner's Dictionaries. Virulence. Available from: https://www.oxfordlearnersdictionaries.com/definition/english/virulence.

[3] Cambridge Dictionary. Virulence. Available from: https://dictionary.cambridge.org/dictionary/english/virulence.

[4] Merriam-Webster. Virulence. Available from: https://www.merriam-webster.com/dictionary/virulence.

[5] Koch R. About bacteriological research. Negotiations at the X. International Medical Congress. [Über bakteriologische Forschung. Aus Verhandlungen des X. Internationalen Medizinischen Kongresses.] Berlin, 1890. Bd. I. Verlag von August Hirschwald, Berlin, 1891. [German]

[6] Falkow S. Molecular Koch's postulates applied to microbial pathogenicity. Rev Infect Dis. 1988; 10 (Suppl 2): S274-S276.

[7] Henle J. Textbook of rational pathology. Second volume. Special part. [Handbuch der rationellen Pathologie. Zweiter Band. Spezieller Abteil.] Druck und Verlag von Friedrich Vieweg und Sohn, Braunschweig, 1853. [German]

[8] Smith HW. A search for transmissible pathogenic characters in invasive strains of Escherichia coli: the discovery of a plasmidcontrolled toxin and a plasmid-controlled lethal character closely associated, or identical, with colicine V. J Gen Microbiol. 1974; 83: 95-111.

[9] Quackenbush RL, Falkow S. Relationship between colicin V activity and virulence in Escherichia coli. Infect Immun. 1979; 24: 562-564.

[10] Williams PH, Warner PJ. ColV plasmid-mediated, colicin V-independent iron uptake system of invasive strains of Escherichia coli. Infect Immun. 1980, 29: 411-416.

[11] Isberg RR, Falkow S. A single genetic locus encoded by Yersinia psendotuberculosis permits invasion of cultured animal cells by Escherichia coli K-12. Nature 1985; 317: 262-264.

[12] Miller VL, Falkow S. Evidence for two genetic loci in Yersinia enterocolitica that can promote invasion of epithelial cells. Infect Immun. 1988; 56: 1242-1248.

[13] Falkow S. Molecular Koch's postulates applied to bacterial pathogenicity - a personal recollection 15 years later. Nat Rev Microbiol. 2004; 2: 67-72.

[14] Bailey MJ, Koronakis V, Schmoll T, et al. Escherichia coli HlyT protein, a transcriptional activator of haemolysin synthesis and secretion, is encoded by the $r f a H(s f r B)$ locus required for expression of sex factor and lipopolysaccharide genes. Mol Microbiol. 1992; 6: 1003-1012. 
[15] Nagy G, Dobrindt U, Grozdanov L, et al. Transcriptional regulation through $\mathrm{RfaH}$ contributes to intestinal colonization by Escherichia coli. FEMS Microbiol Lett. 2005; 244: 173-180.

[16] Blum G, Ott M, Lischewski A, et al. Excision of large DNA regions termed pathogenicity islands from tRNA-specific loci in the chromosome of an Escherichia coli wild-type pathogen. Infect Immun. 1994; 62: 606-614.

[17] Collier RJ. Diphtheria toxin: mode of action and structure. Bacteriol Rev. 1975; 39: 54-85.

[18] Ofek I, Hasty DL, Abraham SN, et al. Role of bacterial lectins in urinary tract infections. In: Emődy L, Pál T, Hacker J, et al. (eds.) Genes and proteins underlying microbial urinary tract virulence. Adv Exp Med Biol. 2000; 485: 183-192.

[19] Peñaranda ME, Evans DG, Murray BE, et al. ST:LT:CFA/II plasmids in enterotoxigenic Escherichia coli belonging to serogroups O6, O8, O80, O85, and O139. J Bacteriol. 1983; 154: 980-983.

[20] Cornelis GR, Boland A, Boyd AP, et al. The virulence plasmid of Yersinia, an antihost genome. Microbiol Mol Biol Rev. 1998; 62: 1315-1352.

[21] El Tahir Y, Skurnik M. YadA, the multifaceted Yersinia adhesin. Int J Med Microbiol. 2001; 291: 209-218.

[22] Emődy L, Heesemann J, Wolf-Watz H, et al. Binding to collagen by Yersinia enterocolitica and Yersinia pseudotuberculosis: evidence for yop $A$-mediated and chromosomally encoded mechanisms. J Bacteriol. 1989; 171: 6674-6679.

[23] Demeure CE, Dussurget O, Mas Fiol GM, et al. Yersinia pestis and plague: an updated view on evolution, virulence determinants, immune subversion, vaccination, and diagnostics. Genes Immun. 2019; 20: 357-370.

[24] Knirel YA, Anisimov AP. Lipopolysaccharide of Yersinia pestis, the cause of plague: structure, genetics, biological properties. Acta Naturae 2012; 4: 46-58.

[25] Montminy SW, Khan N, McGrath S, et al. Virulence factors of Yersinia pestis are overcome by a strong lipopolysaccharide response. Nat Immunol. 2006; 7: 1066-1073.
[26] Achtman M, Zurth K, Morelli G, et al. Yersinia pestis, the cause of plague, is a recently emerged clone of Yersinia pseudotuberculosis. Proc Natl Acad Sci USA 1999; 96: 14043-14048. [Erratum: Proc Natl Acad Sci USA 2000; 97: 8192.]

[27] Quenee LE, Hermanas TM, Ciletti N, et al. Hereditary hemochromatosis restores the virulence of plague vaccine strains. J Infect Dis. 2012; 206: 1050-1058.

[28] Skurnik M, Toivanen P. LcrF is the temperature-regulated activator of the yadA gene of Yersinia enterocolitica and Yersinia pseudotuberculosis. J Bacteriol. 1992; 174: 2047-2051.

[29] Pátri E, Szabó E, Pál T, et al. Thin aggregative fimbriae on uri nary Escherichia coli isolates. Adv Exp Med Biol. 2000; 485: 219-224.

[30] Nagy G, Danino V, Dobrindt U, et al. Down-regulation of key virulence factors makes the Salmonella enterica serovar Typhimurium $r f a H$ mutant a promising live-attenuated vaccine candidate. Infect Immun. 2006; 74: 5914-5925.

[31] Brzuszkiewicz E, Brüggemann $\mathrm{H}$, Liesegang $\mathrm{H}$, et al. How to become a uropathogen: comparative genomic analysis of extraintestinal pathogenic Escherichia coli strains. Proc Natl Acad Sci USA 2006; 103: 12879-12884.

[32] Gordillo Altamirano FL, Barr JJ. Phage therapy in the postantibiotic era. Clin Microbiol Rev. 2019; 32: e00066-18.

[33] Jiang Q, Chen J, Yang C, et al. Quorum sensing: a prospective therapeutic target for bacterial diseases. BioMed Res Int. 2019; 2019: 2015978.

[34] Peterson D, Damsky W, King B. The use of Janus kinase inhibitors in the time of severe acute respiratory syndrome coronavirus 2 (SARS-CoV-2). J Am Acad Dermatol. 2020; 82: e223-e226.

[35] Anisimov AP, Lindler LE, Pier GB. Intraspecific diversity of Yersinia pestis. Clin Microbiol Rev. 2004, 17: 434-464.

(Emődy Levente dr., Pécs, Szigeti út 12., 7624 e-mail: emody.levente@pte.hu

\section{ÁLLÁSAJÁNLAT}

A Szombathelyi Országos Büntetés-végrehajtási Intézet felvételt hirdet főállású, vagy közreműködői szerződéssel (heti meghatározott óraszámban) SZAKORVOS beosztás betöltésére - háziorvos vagy belgyógyász szakorvosi végzettséggel rendelkező - magyar állampolgár, egészségügyileg alkalmas, kifogástalan életvitelü, büntetlen előéletü, érvényes kamarai tagsággal és müködési nyilvántartással rendelkező személyek részére.

Eltéréssel biztosított Egészségügyi törvény szerinti kiemelt jövedelem.

A szakmai önéletrajzokat az alábbi címre várjuk:

Szombathelyi Országos Büntetés-végrehajtási Intézet

9700 Szombathely, Söptei út

e-mail: szombathely.uk@bv.gov.hu

A cikk a Creative Commons Attribution 4.0 International License (https://creativecommons.org/licenses/by/4.0/) feltételei szerint publikált Open Access közlemény, melynek szellemében a cikk bármilyen médiumban szabadon felhasználható, megosztható és újraközölhető, feltéve, hogy az eredeti szerző és a közlés helye, illetve a CC License linkje és az esetlegesen végrehajtott módosítások feltüntetésre kerülnek. (SID_1) 